\title{
Contemporary Tendencies in Third Party Logistics
}

\author{
Aleksandrs Kotlars $^{1}$, Dmitrijs Solovjovs ${ }^{2}$, Valerijs Skribans ${ }^{3}$ \\ Riga Technical University, SESMI institute, Riga, Latvia \\ E-mails: 'aleksandrs.kotlars@gmail.com (corresponding author); \\ 22dmitrijs.solovjovs@rtu.lv; ${ }^{3}$ valerijs.skribans@rtu.lv
}

Received 08 February 2017; accepted 24 March 2017

\begin{abstract}
Contemporary third party logistics (3PL) companies tend to broaden their competences in different fields and apart from traditional logistics services provide various value-added services to their customers. An inductive analysis of 3PL related literature is required, in order to define possible directions for development of contemporary 3PL companies. The purpose of this paper is, foremost, to discover contemporary tendencies of 3PL activities through investigation of literature. Second, to systematically classify 3PL activities discussed in scientific literature. Third, discover areas that require further development. The paper is based on systematic review and classification of articles related to 3PL activities that were published in scientific journals and databases. This paper is organized as follows. First part contains quantitative analysis of literature and description of authors' developed directions of 3PL activities. Subsequent sections contain qualitative review of modern 3PL tendencies by each of pre-defined areas. Last section aims at providing conclusions and suggestions for further research. The key findings are following. Majority of studies of 3PL activities are based on particular business case or survey that does not allow to make conclusion about industry in general. Main emphasis in contemporary research is done on knowledge-based services. It is agreed that core logistics services are tended to be replaced by value-added services.
\end{abstract}

Keywords: third party logistics, 3PL, logistics services, logistics costs.

JEL Classification: L90, M16, R40, R41.

Conference topic: Business Logistic Processes.

\section{Introduction}

In the course of time, as manufacturing begun extensive development and new technologies appeared, number of companies specialized in cargo transportation and storage services has grown. In addition, their integration degree into management of clients' cargo transportation and storage has also increased. In order to support continuous optimization process of logistics and transportation costs and simultaneously concentrate on core activities, many international businesses outsource part of their logistics functions to third party logistics (3PL) companies. This has become a widely used practice in international business due to wide scope of experience, knowledge and resources of 3PL companies, which allows providing transportation and logistics services with lower costs. The main reason of appearance and development of 3PL is considered to be high competition level among businesses in different industries. Under such circumstances, businesses are forced to continuously develop new products, as well as utilize the most efficient way of deliveries to their clients. Over the time 3PL companies has expanded their scope of services which allows them to cover large geographical areas and maintain wide range of products transportation and storage.

Apart from traditional transportation and warehousing services, 3PL companies tend to broaden their competences in different fields and provide various value-added services to their customers. Hence, an inductive analysis of 3PL related literature is required, in order to define possible directions for development of contemporary 3PL companies. The purpose of this paper is, foremost, to discover contemporary tendencies of 3PL activities through investigation of literature. Second, to systematically classify 3PL activities discussed in scientific literature. Third, discover areas that require further development. The paper is based on systematic review and classification of more than 400 articles related to 3PL activities that were published in scientific journals and databases. Only articles that consider 3PL companies as an object and published from year 2007 till 2016 were reviewed. This paper is organized as follows. First section contains quantitative analysis of literature and description of authors' developed directions of 3PL activities. Further sections contain qualitative review of modern 3PL tendencies in frames of following pre-defined areas: Green Logistics and Environmental Issues, Selection and Evaluation Methods of 3PL, Logistics Alliances and Horizontal Cooperation with Partners, Pricing Methods and Costs of 3PL. Last section aims at providing conclusions and suggestions for further research.

(C) 2017 A. Kotlars, D. Solovjovs, V. Skribans. Published by VGTU Press. This is an open-access article distributed under the terms of the Creative Commons Attribution (CC BY 4.0) License, which permits unrestricted use, distribution, and reproduction in any medium, provided the original author and source are credited. 


\section{Literature review}

In order to discover contemporary tendencies of 3PL activities, a systematic literature review was conducted. There is a variety of articles where 3PL theme is touched, however, in many cases authors discuss problems of production companies and propose 3PL solution in order to reach optimization of processes and costs. However, in this study, only articles where 3PL companies are considered as an object of studies, were reviewed. In other words, business activities of 3PL companies is a subject of this study. Selected articles were taken from scientific journals and databases that were published within 10-year period (from 2007 till 2016). According to search criteria, 415 publications were selected and reviewed. As a result of systematic literature review and keyword coding, 11 major groups of articles were defined according to themes and business activities that authors touch in their publications. Last group consists of publications with general review of 3PL activities (e.g. market review, surveys) and will not be discussed in this paper. These themes of publications are listed below.

- Green logistics and environmental issues;

- Selection and evaluation methods of 3PL;

- Performance evaluation and measurement of 3PL companies;

- Utilization of IT by 3PL companies;

-Finance, management and strategy development of 3PL companies;

- Cooperation and synergies between 3PL and customers;

- Logistics alliances and horizontal cooperation with partners;

- Quality management in 3PL companies;

-3 PL services and innovations;

- Pricing methods and costs of 3PL;

- Review of 3PL activities and other topics.

Each of selected articles belong to at least one of above mentioned themes, however, many authors in their publications discussed two or three topics. That is why, it was decided to allocate primary, secondary and tertiary categories to all of 415 publications. Table 1 shows distribution of articles by themes (including primary, secondary and tertiary categories).

Table 1. Distribution of publications by primary, secondary and tertiary themes (Source: made by authors)

\begin{tabular}{l|c|c|c|c}
\hline \multirow{2}{*}{ Groups (themes) } & \multicolumn{3}{c}{ Categories } \\
\cline { 2 - 5 } & Primary (qty) & Primary (\%) & Secondary & Tertiary \\
\hline Green logistics and environmental issues & 14 & $3 \%$ & 7 & 1 \\
\hline Selection and evaluation methods of 3PL & 100 & $24 \%$ & 27 & 1 \\
\hline Performance evaluation and measurement of 3PL companies & 14 & $3 \%$ & 5 & 1 \\
\hline Utilization of IT by 3PL companies & 21 & $5 \%$ & 8 & 1 \\
\hline Finance, management and strategy development of 3PL companies & 27 & $7 \%$ & 17 & 1 \\
\hline Cooperation and synergies between 3PL and customers & 69 & $17 \%$ & 37 & 4 \\
\hline Logistics alliances and horizontal cooperation with partners & 18 & $4 \%$ & 3 & 1 \\
\hline Quality management in 3PL companies & 11 & $3 \%$ & 4 & 2 \\
\hline 3PL services and innovations & 56 & $13 \%$ & 30 & 2 \\
\hline Pricing methods and costs of 3PL & 17 & $4 \%$ & 6 & 1 \\
\hline Review of 3PL activities and other topics & 68 & $16 \%$ & 19 & 1 \\
\hline
\end{tabular}

As it was previously mentioned, in total 415 articles were chosen which satisfy selection criteria. As a result of systematic review, in total 11 major themes were created. Columns "Primary (qty)" and "Primary (\%)" of Table 1 shows distribution of articles by themes according to primary category. Last two columns show number of articles where respected themes were discussed as secondary and tertiary topics. As it is seen, most widely discussed theme is Selection and evaluation methods of 3PL (100 articles, 24\% of total number). It should be admitted that in this case 3PL company cannot treated as an object of a study, due to the fact that process of selection and evaluation is performed by customers. However, this topic is vitally important to 3PL companies due to the fact that understanding of this process and evaluation criteria allows to overcome competitors. Cooperation and synergies between 3PL and customers (69 articles, $17 \%$ of total number) and 3PL services and innovation (56 articles, 13\% of total number) are second and third 
most popular themes discussed by industry leading specialists. It is important to notice that these articles discuss interactions with external environment of 3PL companies. At the same time, less discussed themes are Quality management in 3PL companies (11 articles, 3\% of total number), Performance evaluation and measurement of 3PL companies (14 articles, $3 \%$ of total number) and Pricing methods and costs of 3PL (17 articles, 4\% of total number). Further in this paper each of above mentioned themes will be considered in more details.

\section{Green logistics and environmental issues}

Over the last decade, logistics companies have experienced a significant pressure from governments and customers to adopt green processes. (Perotti et al. 2010) Demand for advanced logistics services grows, third party logistics providers are being requested to provide more environmentally sustainable services. On the one hand, it provides logistics companies various opportunities, but on the other hand, challenges them and forces to translate green efforts into practice (Evangelista 2014). Thus, the concept of sustainability, sustainable development and green logistics has become increasingly influential and widely used by third party logistics providers nowadays (Lagoudis, Shakri 2015). In this chapter contemporary trends of green supply chain management and its influence on companies' performance and corporate social responsibility will be discussed.

Logistics service providers take a variety of approaches to reach environmental sustainability and for this purpose numerous tools are used, including:

- Training for truck drivers to enhance their awareness and monitoring driving speed;

- Using more alternative modes of transportation and bio fuels;

- Reducing energy consumption in warehouses;

- Improving loading capacity;

- Investing in electric vehicles;

- Avoiding empty hauls etc.

Pieters et al. (2012) proposed to categorize these approaches and developed sustainability activity matrix (Table 2). This matrix shows internal approach and aspects, which can be organized by the logistics service providers themselves. External approach includes aspects, which requires logistics service providers to cooperate with players outside organization. Innovating aspects are previously unknown, however, optimizing aim at improving and achieving better results.

Table 2. Sustainability activity matrix (Source: Pieters et al. 2012)

\begin{tabular}{l|l|l}
\cline { 2 - 3 } & \multicolumn{1}{|c}{ Optimizing } & \multicolumn{1}{c}{ Innovating } \\
\hline \multirow{4}{*}{ Internal approach } & Green driving & New software \\
& $\begin{array}{l}\text { Greener trucks } \\
\text { Improve internal planning } \\
\text { Energy saving programs } \\
\text { Increase load rates }\end{array}$ & $\begin{array}{l}\text { Applications } \\
\text { Intermodal } \\
\text { Longer heavier vehicles } \\
\text { Electrical vehicles }\end{array}$ \\
\hline \multirow{3}{*}{ External approach } & $\begin{array}{l}\text { Improve delivery planning } \\
\text { Increase efficiency } \\
\end{array}$ & $\begin{array}{l}\text { Green orders } \\
\text { Developing new concept for delivery } \\
\text { Packaging } \\
\text { Cooperation with stakeholders } \\
\text { Cooperation with competitors }\end{array}$ \\
\hline
\end{tabular}

Environmentally sustainable logistics and green supply chain practices may influence customers' decision on selection of particular logistics service provider (Wolf, Seuring 2010). There are three topics that can be used as decisive criteria and allow to analyze procurement practices between third party logistics and customers:

- Pressures and incentives for sustainable supply chain management. Indeed, customers' demand for green logistics solutions is rising, however, the question of price is more important. That is why transport buyers' put environmental criteria in second or third line.

- Identifying and measuring impacts on sustainable supply chain management. Despite the fact that many third party logistics providers and customers agree to measure emissions caused by transportation activities, there are very few knowledges on how results of these measurements impact company's and logistics service provider's economy.

- Supplier management. Many transport buyers request third party logistics providers for information on their environmental performance. At the same time, compliance with very basic requirements is enough for logistics providers to be qualified and included into tender process. 
Perotti et al. (2012) conducted a multiple case empirical research in order to understand how green supply chain practices may influence third party logistics company's performance. On the one hand, there is a number of green supply chain practices that have certain impact:

- Green supply;

- Distribution strategies and transportation;

- Warehousing and green building;

- Reverse logistics;

- Cooperation with customers;

- Investment recovery;

- Eco-design and packaging;

- Internal management.

On the other hand, performance of a company is evaluated according to three major criteria: environmental; economic; operational.

Results of the research show that highest impact of implementation of green supply chain practices is visible on environmental performance of a companies: reduction of air emissions; reduction of energy consumption; improvement of transportation environmental performance. Medium impact is reflected on economic performance: decrease of costs for materials purchasing; decrease of costs for energy consumption; increase of investments; increase of training costs. Lowest impact is visible on operational performance: increased amount of goods delivered on time; decrease of inventory levels; improved capacity utilization.

Another inductive research (Abbasi, Nilsson 2016) of challenges in developing environmentally sustainable logistical activities discovered four categories of challenges:

- Customer priorities. Involvement of logistics service providers' customers is very important in order to develop and deliver more sustainable solutions. Studies show that most customers have relatively low interest in environmentally sustainable solutions. Besides, customers expect transportation services to be carried out quickly and at the lower price.

- Managerial complexity. It is often difficult to find correct approach of measurement and assessment of sustainable logistical services implementation.

- Network imbalance. Ability of logistics service providers to balance flows of goods and resources in distribution network is often considered as a major challenge. Such type of imbalance appears due to several restrictions, e.g. delivery time, weight and volume of cargo.

- Technological and legislative uncertainties. Such factors as uncertainty about future fossil-free fuels and infrastructural changes, as well as uncertainty in legislation and regulations influence willingness of logistics service providers to invest in environmentally sustainable logistical activities.

Perotti et al. (2010) and Evangelista (2014) investigated motivations, drivers and barriers of green supply chain practices' adaptation by logistics service providers. In order to understand what urges companies to implement green supply chain practices, possible internal and external motivation factors were divided into several groups. Afterwards, in frames of questionnaire, these factors were evaluated by leading logistics service providers. Results show that very significant internal factors that motivate implementation of green supply chain practices are: environmental reputation; company's environmental mission; policy of a parent company; commitment of top-level managers; liability of disposal of hazardous materials. Following external factors were pointed out: national and regional environmental regulations; national and regional resource saving and conservation regulations; establishing company green image; environmental awareness of customers and consumers. At the same time, research revealed several barriers towards green supply chain practices' adaptation by logistics service providers: high investments; lack of customer's interest in green logistics services; lack of negative economic impact; difficulties in identifying and measuring of economic effects of green supply chain practices; lack of competences in implementation of practices.

Lagoudis and Shakri (2015) proposed a model to capture, calculate and manage emissions activities in transportation network that is aimed to help logistics service providers to enable corporate social responsibility practices. The research was carried out in three phases: development of footprint - tracking model; testing of a model assuming several scenarios that are based on the industry inputs; optimization of a model by implementation of various restrictions (cost, lead-time, cargo weight). As the result, research provided an insight into the impact of redistribution of cargo weight between different modes of transport on carbon emissions, cost and lead-time variations.

Nemoto and Rothengatter (2012) described a problem that is caused by demands of just-in-time or just-in-sequence deliveries, that forces logistics service providers to make frequent and small sized shipments of goods. At the same time, it usually increases road freight traffic, as well as results in negative environmental impacts. A milk-run delivery and collection concept was proposed, that allows to combine several shippers and consignees in single distribution vehicle and reduce number of trips needed to serve customers. It is emphasized that this concept is widely used in automotive spare parts distribution, allows efficient utilization of truck space and seems highly beneficial in congested urban environments. 


\section{Selection and evaluation methods of 3PL}

The outsourcing of logistical functions to 3PL service providers has become an increasingly powerful trend in modern multinational companies (Qureshi et al. 2007). It is supported by many factors, such as globalization, deregulation, corporate restructuring, changes in logistics management and labor issues (Aguezzoul et al. 2006). 3PL service provider business is developing as a result of the emerging demand of advanced logistics services. The role of logistics providers is changing both in content and in complexity. According to Sun et al. (2010), cooperation between shippers and 3PL companies is an intended continuous relationship.

Evaluation and selection of 3PL is a critical step in the logistics outsourcing process (Bansal et al. 2014). An appropriate 3PL will help the outsourcing firms to reduce capital investment in facilities, equipment, information technology and manpower, as well as increase their flexibility in adapting to changes in the market (Ho et al. 2009). Evaluating and selecting 3PL providers can be regarded as a multi-criteria decision making (MCDM) process in which a decision maker chooses, under several selection criteria, the best option among alternatives (Soh 2010; Chunhao et al. 2008; Favaretto et al. 2009). Traditionally, the selection process often depended on subjective judgment on the basis of the decision-makers' individual understanding of 3PL providers. At the same time, selecting the most suitable 3PL provider involves much more than scanning a series of price lists. The choice relies on a systematic consideration that involves a wide range of criteria (Wang et al. 2015; Huo, Wei 2008).

Selection of 3PL starts with the establishment of decision criteria, which are relevant to the identification and evaluation of candidates with the highest potential for meeting client's service needs consistently and at an affordable price (Perçin, Min 2013). In literature there are different approaches of 3PL selection criteria definitions proposed by leading specialists. Jharkharia and Shankar (2007) identified a hierarchical scheme composed of three levels of criteria: determinants, dimensions and enablers. Determinants are 3PL provider's compatibility, price level, quality and reputation. There are four dimensions in frames of which potential suppliers are evaluated: long-term relationship, operational performance, financial performance and risk management. Each of these dimensions has corresponding enablers or attributes. Hwang and Chen (2013), Hwang and Chang (2015) proposed classification of selection criteria into six dimensions: service, performance, cost, quality, assurance, IT, intangible. Zhang et al. (2012) identified five major categories of selection criteria: operational capabilities, finance performance, improvement and compatibility, client relationship, enterprise cultural. It is also possible to find other frameworks, e.g. evaluation factors may be divided into three groups - contextual, uncertainty and implementation (Rattanawiboonsom 2014). It is important to mention that selection factors divided among these groups are considered from client's perspective and its ability to directly or indirectly influence them:

- Contextual factors. These factors are considered to be the basis for successful selection of 3PL provider. However, they are not changeable or even not under control of client. As an example, following factors can be mentioned: 3PL partner's reputation on market, company's size and age, ownership;

- Uncertainty factors. This group contains factors that potentially might be under control of client or at least partially influenced. After nomination of 3PL provider and implementation of partnership, trucking and sustaining of performance is conducted. As a result of these activities, client in cooperation with provider is able to fine - tune uncertainty factors. Following factors are included in this group: 3PL partner's dispute solving approach, behavior of people within provider's organization; provider's ability to be constantly updated to new technologies;

- Implementation factors. These are critical factors that client has to take into account in order to select most appropriate 3PL partner. Basically, they reflect competitiveness of particular 3PL provider. Furthermore, these factors are considered to be under control of client and can be completely influenced during selection process. Influence can be seen as potential 3PL providers receive client's feedback after recurrent request for proposal (RFP) stage with recommendations for improvement. Following factors are included in this group: price level offered by 3PL provider, service quality including transportation lead time, pro-posed bonus-malus system, provider's responsiveness to client's requests, understanding client's supply chain needs, support from 3PL provider's top management etc.).

The process of 3PL provider's selection contains several steps that are usually conducted by businesses. Depending on company's profile and its scope of activities, this procedure might take up to several months. Figure 1 reflects general milestones of selection process.

The first steps conducted by businesses are analysis of needs and definition of goal. According to defined goal (e.g. to acquire full truck load and full container load cross border transportation services within Europe), decision concerning involvement of particular 3PL providers, who might correspond company's needs, shall be made. Expert team, which is often named performance evaluation team, consists of company's procurement personnel in charge of evaluation and ranking involved 3PL providers according to defined criteria. One of key important steps is definition of 3PL evaluation criteria. These criteria will be used by performance evaluation team in scope of particular selection method. First involvement of potential 3PL provider is so called request for information (RFI) or market screening. As the result of this activity, following information about 3PL providers can be gathered: interest and capabilities to provide requested services; contact information; quality certification; information technology systems capabilities; fleet 
size etc. As soon, as RFI is completed, draft selection of most suitable 3PL providers is conducted and request for proposal (RFP) is implemented. During RFP phase 3PL providers are asked to make commercial proposals according to company's defined needs. In practice, there may be several RFP rounds, so 3PL providers are able to make adjustments in their commercial proposals ac-cording to given feedbacks. Comprehensive evaluation of suppliers is done by performance evaluation team. There are various methods mentioned in literature and used by leading specialists. These methods will be later described in this article. Final steps are selection of most suitable 3PL provider, implementation of partnership and sustaining performance. It is necessary to mention that trucking of selected provider's performance is very crucial due to the fact that it will allows to implement corrections in evaluation criteria for subsequent selections.

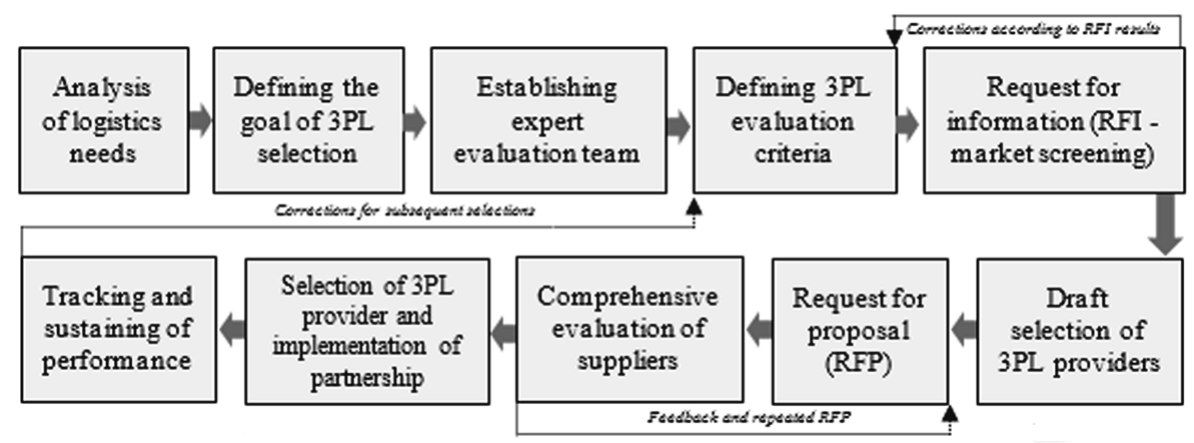

Fig. 1. Selection steps of 3PL provider (Source: made by authors)

As a result of literature analysis, various techniques were identified that are used for comprehensive evaluation of 3PL suppliers. In order to systematically organize these techniques, it was decided to make two levels of categories: major and minor (subcategories), as it is shown in Figure 2. There are in total 16 minor categories. After interpretation of minor categories, particular regularity was spotted, that allowed to combine them into four major categories, which are mostly considered to be approaches of 3PL selection.

\begin{tabular}{|c|c|c|c|}
\hline \multicolumn{3}{|c|}{ 3PL Selection } & \\
\hline $\begin{array}{l}\text { Multi-attribute } \\
\text { decision-making }\end{array}$ & $\begin{array}{l}\text { Artificial } \\
\text { intelligence }\end{array}$ & $\begin{array}{l}\text { Mathematical } \\
\text { programming }\end{array}$ & $\begin{array}{l}\text { Integrated } \\
\text { approach }\end{array}$ \\
\hline $\begin{array}{c}\text { Decision-making trial } \\
\text { and evaluation } \\
\text { laboratory } \\
\text { (DEMATEL) }\end{array}$ & $\begin{array}{c}\text { Analytical hierarchy } \\
\text { process (AHP) }\end{array}$ & Fuzzy logic & $\begin{array}{c}\text { Preference ranking } \\
\text { organization method } \\
\text { for enrichment of } \\
\text { evaluations } \\
\text { (PROMETHEE) }\end{array}$ \\
\hline $\begin{array}{l}\text { Data envelopment } \\
\text { analysis (DEA) }\end{array}$ & $\begin{array}{l}\text { Quality function } \\
\text { deployment (DEA) }\end{array}$ & Grey system analysis & Delphi method \\
\hline $\begin{array}{l}\text { Technique for order } \\
\text { preference by } \\
\text { similarity to ideal } \\
\text { solution (TOPSIS) }\end{array}$ & $\begin{array}{c}\text { Particle swarm } \\
\text { optimization (PSO) }\end{array}$ & $\begin{array}{l}\text { Linear \& non-linear } \\
\text { programming }\end{array}$ & $\begin{array}{c}\text { Interpretive structural } \\
\text { modeling (ISM) }\end{array}$ \\
\hline $\begin{array}{l}\text { Elimination and } \\
\text { choice expressing } \\
\text { reality (ELECTRE) }\end{array}$ & Graphical analysis & Data cluster analysis & $\begin{array}{l}\text { Analytical network } \\
\text { process (ANP) }\end{array}$ \\
\hline
\end{tabular}

Fig. 2. 3PL selection approaches and techniques (Source: made by authors)

Majority of articles describe MADM (multiple-attribute decision-making) approach, as possibility for selection of 3PL. This category includes such techniques as AHP, ANP, ISM, TOPSIS, DEMATEL, ELECTRE, QFD, fuzzy logic, PROMETHEE. Second largest category (not counting Integrated approach) is Mathematical programming approach, which includes DEA, PSO, linear and nonlinear programming, grey system analysis, data cluster analysis. Artificial intelligence approach of 3PL selection utilizes Delphi method. Integrated approach does not foresee usage of any unique techniques. However, it was emphasized due to the fact, that many authors suggest to use combination of two 
and more methods, e.g. fuzzy AHP and TOPSIS on different stages of 3PL selection process. Very often such techniques as qualitative research or graphical analysis (not included in previous major categories) are used in frames of integrated 3PL selection approach.

\section{Logistics alliances and horizontal cooperation with partners}

Logistics alliances can be described as long-term and voluntary relationships between two or more independent actors of a supply chain (Brekalo, Alber 2016). Looking from perspective of 3PL provider, alliances may be either horizontal or vertical. Vertical logistics alliances are long-term relationships between logistics service providers and customers. In frames of this cooperation, logistics service provider secures all (e.g. fourth party logistics contact) or considerable number of logistics activities for customer. Horizontal logistics alliances are mutually initiated long-term relationships between different logistics service providers that work on the same part of supply chain. In international practice 3PL-4PL relationships can be often observed, where 4PL is defined as a consulting firm that integrates and manages customer's resources and providers, including 3PL (Zhai et al. 2010; Xu et al. 2010). However, mutual relationships 3PL-3PL and 3PL-2PL also can be related to horizontal logistics alliances. Brekalo and Albers (2016) defined main conceptual differences between vertical and horizontal logistics alliances.

Table 3. Sustainability activity matrix (Source: made by authors)

\begin{tabular}{l|l|l}
\cline { 2 - 3 } & \multicolumn{1}{|c}{ Vertical alliance } & \multicolumn{1}{c}{ Horizontal alliance } \\
\hline Motivation & $\begin{array}{l}\text { Primarily formed to enhance productivity and ser- } \\
\text { vices for the client. }\end{array}$ & $\begin{array}{l}\text { Efficiency increase and improved service offer- } \\
\text { ings for each individual logistics service provider } \\
\text { in alliance. }\end{array}$ \\
\hline $\begin{array}{l}\text { Nature of the } \\
\text { relationship }\end{array}$ & $\begin{array}{l}\text { Built on differentiation of assets, capabilities and pur- } \\
\text { pose of each partner. Low threat of opportunism. }\end{array}$ & $\begin{array}{l}\text { Partners are usually competitors. Increased threat } \\
\text { of opportunism. }\end{array}$ \\
\hline Interdependence & $\begin{array}{l}\text { Resource interdependence among partners due to } \\
\text { complementary nature of their resources. }\end{array}$ & $\begin{array}{l}\text { Partners are not linked to each other's } \\
\text { resources and may run business independently. }\end{array}$ \\
\hline
\end{tabular}

Horizontal logistics alliances are well developed in maritime shipping and airline industries, where different logistics service providers offer their services on a specific transportation line with collective tariffs and identical service levels (Verstrepen et al. 2009). It is seen as a viable strategy for improving logistics performance and thus performance of associated supply chain. Horizontal alliances occur at tactical level due to inefficiencies in fill rate of vehicles or warehouse capacities, as well as strategic level in order to share common distribution planning platform (Sanchez Rodrigues et al. 2015).

Benefits and motivating factors of horizontal alliances. Verstrepen et al. (2009) emphasized internal and external motives for horizontal cooperation. Internal motives include: better utilization of existing infrastructure and assets; increasing capacity; extending geographical coverage; improving service; diversification. External motives include: improving customers' loyalty, dealing with fluctuation in demand and flexible capacity; changes of economic environment; industry changes, such as new competition, price erosion. Sanchez Rodrigues et al. (2015) and Cruijssen et al. (2007) stated benefits of development of horizontal alliances: optimization of logistics costs; fulfillment of distribution network; possibility to enter the tendering process of large customers; sharing of "good practices".

Impediments and barriers of horizontal alliances. Following blocking points are identified: lack of knowledge about partner's assets and capabilities; problem of determining and dividing gains of shared vehicles or network; unequal negotiation positions of partners; uneven adaptation of information and communication technology solution (Sanchez Rodrigues et al. 2015; Cruijssen et al. 2007).

\section{Pricing methods and costs of 3PL}

Cost structure of 3PL providers is mainly made up of direct costs (purchase of transportation and warehousing services from subcontractors). In order to optimize these cost, companies carry out multi-customer share resources, namely integrate various customers into their network. As number of customers grow, cost calculation and hence pricing become more difficult. Many traditional costing systems are founded on volume-based allocation (Wei, Jun 2007). According to Gríful-Miquela (2001), main functions that any costing model should perform are:

- Measurement of the cost of goods and services sold for financial purposes;

- Estimation of the cost of activities, products, services and customers;

- Provide economic feedback to managers and staff in general about process efficiency.

Nowadays activity-based costing (ABC) is widely used by 3PL companies. It is centered on company's activities, by recognizing and measuring the cost, dynamically reflecting all the activities, including value-added activities, as well as minimizing wastes (Lingling, Yong 2011). The main difference between traditional costing models and ABC is that $\mathrm{ABC}$ takes into account non-volume related overhead costs (Gríful-Miquela 2001). 


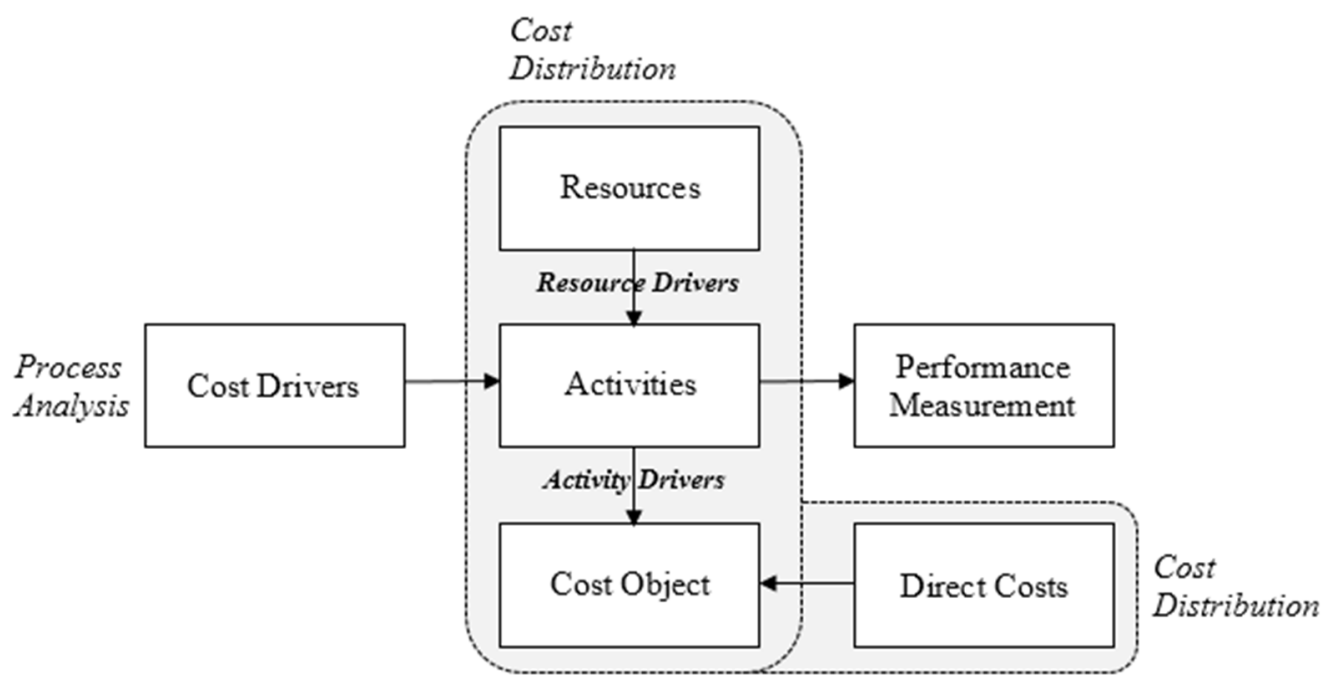

Fig. 3. Activity-based costing model (Source: adopted from Wei, Jun 2007)

Within ABC model, allocation of costs is done in two steps. Firstly, indirect costs (resources) are allocated to the services using resource drivers (on basis of activities that are performed in order to produce service). In scope of 3PL, indirect costs may include: wage; equipment; space; materials. Activities are defined as repetitive actions in order to produce service. In 3PL, activities may include: order reception, entry and approval; invoicing; cargo sorting; labeling; packaging etc. Cost drivers, however, are factors that cause any change in the costs of activity. For instance, order reception, entry and approval is influenced by order volume received from customer. Secondly, costs of activities are allocated to costs object using activity drivers. In scope of 3PL, cost object may be an order or request for quotation, that is received from customer.

In addition to integration of multi-customers into 3PL provider's network, there are also other factors that sophisticate price building process:

- Heterogeneous clients' demand for logistics services. Zhang et al. (2015) proposed to use dynamics pricing strategy and develop a model which computes optimal freight rates taking into account 3PL provider's current holding costs and available transportation capacity. This model employs multinomial logit function based method to estimate customers' choices of delivery dates. Assuming that clients' demand is heterogeneous, maximum likelihood estimation is employed for regressing multinomial logit function.

- Incomplete information. 3PL provider's and client's operating costs are private information. Li (2013) developed a bilateral bargaining model (based on Bayesian game theory) taking into account the switching cost to analyze pricing decision between customer and 3PL provider.

- Cognition of customer's requirements. The design and application of 3PL services should be implemented under a comprehensive quality evaluation system. Zhou (2009) developed service cost relation technology to design, control, operate and manage 3PL projects. Service cost relation technology tends to transfer customers' requirements to service costs.

\section{Conclusions}

The main contribution of this article is definition and classification of contemporary tendencies of 3PL activities, as well as discovery of areas for further investigation. As a result of systematic literature review, following groups were defined and studies in this paper according to themes and business activities of 3PL: Green logistics and environmental issues; Selection and evaluation methods of 3PL; Performance evaluation and measurement of 3PL companies; Utilization of IT by 3PL companies; Finance, management and strategy development of 3PL companies; Cooperation and synergies between 3PL and customers; Logistics alliances and horizontal cooperation with partners; Quality management in 3PL companies; 3PL services and innovations; Pricing methods and costs of 3PL. Most popular themes discussed among industry specialists are related to interactions with external environment of 3PL companies, which are 3PL selection, cooperation with clients and innovative services. Less discussed themes are related to internal environment, which are performance evaluation of 3PL, quality management and costs of 3PL.

General finding related to all publications are following. Many authors refer to resource-based view theory in their studies, for instance while evaluating performance of 3PL or describing pricing methods, thus consider 3PL's resources as key factor to gain competitiveness. Majority of studies of 3PL activities are based on particular case study or survey, that is limited by narrow group of companies, country or region. It does not allow to make conclusion about industry in general, since such studies may contain uncertainties or particular qualities that are specific to economy of 
country or region. Hence, results of these studies cannot be easily applied to other business cases. Many authors in their studies do not separate 3PL by types of services while, for example, studying environmental issues or logistics alliances. Though, it is important take into account types of services 3PL company is specialized in, since it may influence strategies, performance and tools.

Findings related to specific area of 3PL activities are following. MADM analysis, that is widely utilized to perform evaluation of 3PL companies, give opportunity to determine best suiting logistics partner as a result of ranking process. However, it does not provide clear statement of benefits that could be gained by client, if particular logistics partner is chosen. Many of currently applied methods do not provide decision makers enough flexibility in order to understand, how might positioning of particular logistics provider be affected, if any of attributes is changed. Application of MADM analysis does not allow decision makers to forecast, how further cooperation with particular 3PL company after certain period of time might affect their business.

Main motivating factors to apply practices of green logistics are reputation of 3PL, which, according to studies, is more important for companies than environmental awareness. In addition, many contemporary 3PL companies have lack of knowledge to measure their environmental impact, hence more studies are required in order to develop approachable framework for measurement of environmental impact.

Despite high competition among 3PL, studies show that horizontal alliances between several 3PL companies are still popular. However, they are in limited scope (mostly specific operational division) and mostly occur on tactical level due to inefficiencies in fill rate of capacities.

Main emphasis in contemporary research is done on knowledge-based services. Many specialists agree that core logistics services are tended to be replaced by value-added services. Only by innovating services and improving service level, 3PL providers can enhance customer satisfaction and establish long-term cooperation.

\section{Acknowledgements}

This work was developed in the National Research Program 5.2. "Economic Transformation, Smart Growth, Governance and Legal Framework for the State and Society for Sustainable Development - a New Approach to the Creation of a Sustainable Learning Community [VPP EKOSOC-LV 5.2.1.].

\section{References}

Abbasi, M.; Nilsson, F. 2016. Developing environmentally sustainable logistics. exploring themes and challenges from a logistics service providers' perspective, Transportation Research Part D: Transport and Environment 46: 273-283. https://doi.org/10.1016/j.trd.2016.04.004

Aguezzoul, A.; Rabenasolo, B.; Jolly-Desodt, A. 2006. Multicriteria decision aid tool for third-party logistics providers' selection, in 2006 International Conference on Service Systems and Service Management, 25-27 October 2016, Troyes, 912-916. https://doi.org/10.1109/ICSSSM.2006.320753

Bansal, A.; Kumar, P.; Issar, S. 2014. 3PL selection: a multi-criteria decision making approach, in IEEE International Conference on Industrial Engineering and Engineering Management, 981-985.

Brekalo, L.; Albers, S. 2016. Effective logistics alliance design and management, International Journal of Physical Distribution and Logistics Management 46(2): 212-240. https://doi.org/10.1108/IJPDLM-08-2014-0201

Chunhao, L.; Yonghe, S.; Yuanwei, D. 2008. Selection of 3PL service suppliers using a fuzzy analytic network process, in Chinese Control and Decision Conference (CCDC 2008), 2-4 July 2008, 2174-2179. https://doi.org/10.1109/CCDC.2008.4597709

Cruijssen, F.; Dullaert, W.; Fleuren, H. 2007. Horizontal cooperation in transport and logistics: a literature review, Transportation Journal 46(3): 22-39.

Evangelista, P. 2014. Environmental sustainability practices in the transport and logistics service industry: AN exploratory case study investigation, Research in Transportation Business and Management 12: 63-72. https://doi.org/10.1016/j.rtbm.2014.10.002

Favaretto, F.; Vieira, G. E.; Carretero-Dias, L. E. 2009. A brief literature review on decision methods analysis for 3PL selection, in IEEE/INFORMS International Conference on Service Operations, Logistics and Informatics (SOLI 2009), 22-24 July 2009, 735-740. https://doi.org/10.1109/SOLI.2009.5204030

Gríful-Miquela, C. 2001. Activity-based costing methodology for third-party logistics companies, International Advances in Economic Research 7(1): 133-146. https://doi.org/10.1007/BF02296598

Ho, W.; Bennett, D. J.; Mak, K. L.; Chuah, K. B.; Lee, C. K. M.; Hall, M. J. 2009. Strategic logistics outsourcing: an integrated QFD and AHP approach, in IEEE International Conference on Industrial Engineering and Engineering Management, $1434-1438$.

Huo, H.; Wei, Z. 2008. Selection of third party logistics providers based on modified grey multi-hierarchical evaluation method, in Chinese Control and Decision Conference (CCDC 2008), 2363-2368.

Hwang, B.; Chang, T. 2015. 3PL selection criteria and their correlations of external environmental factors-an empirical study of taiwan IC industry, in International Conference on Logistics, Informatics and Service Science (LISS), 27-29 July 2015. https://doi.org/10.1109/LISS.2015.7369643

Hwang, B.; Chen, M. 2013. Key selection criteria for third party logistics in the IC manufacturing industry, in Proceedings of 2013 IEEE International Conference on Service Operations and Logistics, and Informatics (SOLI 2013), 28-30 July 2013, $445-449$. https://doi.org/10.1109/SOLI.2013.6611456 
Jharkharia, S.; Shankar, R. 2007. Selection of logistics service provider: an analytic network process (ANP) approach, Omega 35(3): 274 289. https://doi.org/10.1016/j.omega.2005.06.005

Lagoudis, I. N.; Shakri, A. R. 2015. A framework for measuring carbon emissions for inbound transportation and distribution networks, Research in Transportation Business and Management 17: 53-64. https://doi.org/10.1016/j.rtbm.2015.11.001

Li, F. 2013. Outsourcing pricing between 3PL and manufacturer based on asymmetric information, in Proceedings of International Conference on Service Science (ICSS), 192-195.

Lingling, H.; Yong, W. 2011. Apply activity-based costing to the costing management of third-party logistic company, in International Conference on Business Management and Electronic Information (BMEI), 13-15 May 2011, 1486-1488. https://doi.org/10.1109/ICBMEI.2011.5916979

Nemoto, T.; Rothengatter, W. 2012. Efficient green logistics in urban areas: Milk run logistics in the automotive industry, in Roger, L. M.; Anthony, D. M.; Masanobu, K.; Haixiao, P. (Eds.). Sustainable Transport for Chinese Cities. Transport and Sustainability. Vol. 3. Lisbon: Emerald Group Publishing Limited, 319-337. https://doi.org/10.1108/S2044-9941(2012)0000003017

Perçin, S.; Min, H. 2013. A hybrid quality function deployment and fuzzy decision-making methodology for the optimal selection of thirdparty logistics service providers, International Journal of Logistics Research and Applications 16(5): 380-397. https://doi.org/10.1080/13675567.2013.815696

Perotti, S. Micheli, G. J. L.; Cagno, E. 2010. Green supply chain practices (GSCP) adoption: understanding motivations and barriers among 3PLs, in Proceedings of APMS 2010 - International Conference on Advances in Production Management Systems.

Perotti, S.; Zorzini, M.; Cagno, E.; Micheli, G. J. L. 2012. Green supply chain practices and company performance: the case of 3PLs in Italy, International Journal of Physical Distribution and Logistics Management 42(7): 640-672. https://doi.org/10.1108/09600031211258138

Pieters, R.; Glöckner, H.; Omta, O.; Weijers, S. 2012. Dutch logistics service providers and sustainable physical distribution: searching for focus, International Food and Agribusiness Management Review 15(SPECIALISSUEB): 107-126.

Qureshi, M. N.; Kumar, D.; Kumar, P. 2007. Selection of potential 3PL services providers using TOPSIS with interval data, in 2007 IEEE International Conference on Industrial Engineering and Engineering Management, 2-4 December 2007, $1512-1516$. https://doi.org/10.1109/IEEM.2007.4419445

Rattanawiboonsom, V. 2014. Effective criteria for se-lecting third-party logistics providers: the case of thai automotive industry, World Review of Business Research 4(2): 196-205.

Sanchez Rodrigues, V.; Harris, I.; Mason, R. 2015. Horizontal logistics collaboration for enhanced supply chain performance: an international retail perspective, Supply Chain Management 20(6): 631-647. https://doi.org/10.1108/SCM-06-2015-0218

Soh, S. 2010. A decision model for evaluating third-party logistics providers using fuzzy analytic hierarchy process, African Journal of Business Management 4(3): 339-349.

Sun, C.; Pan, Y.; Bi, R. 2010. Study on third-party logistics service provider selection evaluation indices system based on analytic network process with BOCR, in International Conference on Logistics Systems and Intelligent Management (CLSIM 2010) 2: 1013-1017.

Verstrepen, S.; Cools, M.; Cruijssen, F.; Dullaert, W. 2009. A dynamic framework for managing horizontal cooperation in logistics, International Journal of Logistics Systems and Management 5(3-4): 228-248. https://doi.org/10.1504/IJLSM.2009.022497

Wang, J.; Wang, M.; Liu, F.; Chen, H. 2015. Multistakeholder strategic third-party logistics provider selection: a real case in china, Transportation Journal 54(3): 312-338. https://doi.org/10.5325/transportationj.54.3.0312

Wei, X.; Jun, L. 2007. A practical model for cost calculation in third party logistics distribution centre based on activity-based costing. Hunan provincial laboratory of logistics information and simulation technology.

Wolf, C.; Seuring, S. 2010. Environmental impacts as buying criteria for third party logistical services, International Journal of Physical Distribution and Logistics Management 40(1-2): 84-102. https://doi.org/10.1108/09600031011020377

Xu, Y.; Zhang, M.; Tang, S. 2010. Research onWorkflow Model of Cooperation between 4PLs and 3PLs based on Petri-net, in $20103^{\text {rd }}$ International Conference on Information Management, Innovation Management and Industrial Engineering.

Zhai, L.; Lu, L.; Zhang, Y. 2010. Study on usability evaluation of fourth party logistics platform, in $3^{\text {rd }}$ International Symposium on Electronic Commerce and Security, ISECS 2010, 109-113.

Zhang, G.; Shang, J.; Li, W. 2012. An information granulation entropy-based model for third-party logistics providers evaluation, International Journal of Production Research 50(1): 177-190. https://doi.org/10.1080/00207543.2011.571453

Zhang, J.; Nault, B. R.; Tu, Y. 2015. A dynamic pricing strategy for a 3PL provider with heterogeneous customers, International Journal of Production Economics 169: 31-43. https://doi.org/10.1016/j.ijpe.2015.07.017

Zhou, J. 2009. Study on third party logistics design model of SCR, in WiCOM'09 Proceedings of the $5^{\text {th }}$ International Conference on Wireless Communications, Networking and Mobile Computing, 24-26 September 2009, Beijing, China. 